\title{
Margaret McCartney: The cult of CPR
}

\author{
Margaret McCartney general practitioner
}

Glasgow

CPR, again. The cultural significance we afford cardiopulmonary resuscitation has reached the status of a cult. No other medical intervention that we don't recommend on the basis of efficacy and adverse effects provokes such angst.

It was acceptable 20 years ago to tell patients and families that dying was inevitable and imminent. Side wards were organised, if possible. Families were called to bedsides at home. Syringe drivers with generous morphine were obtained. Relatives often stayed with their dying family member at all hours.

A discreet entry was made in the notes: not for resuscitation. The nurse in charge of the ward, or the district nurse, ensured that this was honoured. In hospital, cardiac monitors were removed, to avoid distress and panic from seeing irregular beats, or none at all. Blood tests were done only if they would provide information to relieve symptoms. Fluid was given if the patient wished, even if swallowing was difficult. In short, the medical care was gentle and respectful, though often imperfect.

The key failing in this otherwise realistic model, as judged with hindsight, is that the patient and family are not explicitly notified that a "do not resuscitate" notice has been placed. The opportunity for a second opinion, in cases of disagreement, is lost.

Many good intentions have crossed the path of dying patients since. We've had forms, lined with red, that needed medical signatures and rank to ensure that CPR was not performed. We've had the Liverpool Care Pathway, which aimed to standardise the care of dying people but became notorious. Some professionals clearly didn't read the explicit instructions it contained, which said that oral fluids can be given: as a result, they withheld fluids and caused unnecessary suffering.

Then came the judgment in the case of Janet Tracey, ${ }^{1}$ where the Court of Appeal for England and Wales found that a "do not attempt CPR" notice had been done without discussing it with the patient, breaching her rights. ${ }^{2}$ We now have the ReSPECT form, ${ }^{3}$ this time lined with purple, with the admirable ambition of making an entire end of life plan clear across services and time.

\begin{abstract}
We don't require consent not to do inappropriate cardiac transplants or not to admit people to intensive care
\end{abstract}

What still concerns me, however, is that CPR remains sacred. Doctors must still inform the patient and/or family that CPR itself will not be done, in a process that often appears like seeking consent—but not to do something that shouldn't have been offered. On many occasions, this will be entirely right and proper. On others, it will not. No one should underestimate the difficulty of explaining the forms that must be completed to enable peaceful dying to people and families who are coming to terms with mortality. There's a dichotomy: we don't require consent not to do inappropriate cardiac transplants or not to admit people to intensive care.

Instead, we should explain the circumstances and likely prognosis and should make offers of care that are likely to improve the quality of remaining life and of death. It's only right that patients should know all details they'd like to know and that they have full access to their notes. People should be able to choose between the rational offers their professionals make.

For many, however, juxtaposing the agreed plan to seek a comfortable and gentle death with the charade of seeking "consent" for not doing CPR-when CPR would have simply been inappropriate to offer-is jarring. No matter how sensitively it's done, no matter how kindly meant, many patients and families have told me how traumatic and difficult this information was to receive.

Courts have said that distress is acceptable but that harm is not: the patient must be consulted "unless [the clinician] thinks that the patient will be distressed by being consulted and that that distress might cause the patient harm." I'm not sure that I can distinguish the two prospectively.

Competing interests: See www.bmj.com/about-bmj/freelancecontributors/margaret-mccartney.

Provenance and peer review: Commissioned; not externally peer reviewed.

Follow Margaret on Twitter, @mgtmccartney 
Court of Appeal. Master of the Rolls Lord Justice Longmore and Lord Justice Ryder: Janet Tracey judgment [2014] EWCA Civ 822. https://www.judiciary.gov.uk/wp-content/uploads/ 2014/06/tracey-approved.pdf.

2 Sokol DK. Cautionary tales about DNACPR. BMJ 2016;358:i26. doi:10.1136/bmj.i26 pmid: 26733107.
3 Example of ReSPECT form. 2017. www.bmj.com/content/bmj/suppl/2017/02/28/bmj.j876. DC1/pitd037468.w1.pdf.

Published by the BMJ Publishing Group Limited. For permission to use (where not already granted under a licence) please go to http://group.bmj.com/group/rights-licensing/ permissions 